\title{
Piotr Buława
}

Uniwersytet Śląski w Katowicach, Polska

piotr@bulawa.com.pl

ORCID: 0000-0001-5368-1020

\section{Institution of taxing discretion: between tax law and taxing arbitrariness $^{1}$}

\begin{abstract}
Taxing discretion disrupts the dichotomous nature of tax law provisions, especially if it concerns tax liabilities. This institution may even be considered arbitrary and deemed not applicable in the Czech Republic. An analysis of English and German law indicates that taxing discretion is inevitable but may be effectively limited, e.g. by introducing a legal doctrine stating that exercise of taxing discretion is bound by the purposes of an act of Parliament granting taxing discretion and by judicial review. In the Czech Republic, taxing discretion is limited by administrative guidelines and judicial review, but further improvements are advisable. This would allow to reintroduce tax cancellation based on taxing discretion into Czech law.
\end{abstract}

KEYWORDS

tax, discretion, arbitrariness, judicial review

\section{Introduction}

It is often assumed that tax law provisions should be precise and unambiguous, i.e. they should be dichotomous in nature. In an exemplary situation, a legal act stipulates certain preconditions for specific facts of the matter. ${ }^{2}$ Therefore, particular factual circumstances may only fulfil these preconditions either fully or not at all. There is no middle ground between the two options. However, taxing discretion (Czech: správní uvážení, German: Ermessen) calls the above-mentioned exemplary situation into question. The classic struc-

1 The article was prepared within the framework of the project Annulment of Tax Obligations - A Comparative Study. The project is being carried out at the Faculty of Law and Administration, University of Silesia in Katowice, Poland. I am the manager and sole performer of the project; its research supervisor is dr hab. Marek Zdebel. The project is financed by the Polish National Science Centre (NCN) under decision no. 2016/23/N/HS5/00157.

2 Tipke, K. and Kruse, H.W. (eds.), Abgabenordnung. Finanzgerichtsordnung. Kommentar [Fiscal Code and Code of Procedure for Fiscal Courts: Commentary]. Köln 2014, § 5, p. 3. 
ture of legal norms (hypothesis, disposition and sanction) leaves no room for taxing discretion. A disposition stipulates what should be done if the hypothesis is fulfilled. Then, a sanction indicates legal consequences (e.g. means of enforcement) when the disposition is not implemented. ${ }^{3}$

Such a discrepancy may even result in radical opinions that taxing discretion is an arbitrary institution, especially in case of an obligation to pay tax liabilities. In the Czech Tax Ordinance of $2009^{4}$ in the original version, Parliament completely removed the possibility to cancel tax liabilities (Czech: promitnutí daně) under the tax authority's discretion. The justification for the draft of the Income Tax Amendment $\mathrm{Act}^{5}$ states that such a removal should (i) reduce risk of corruption, (ii) eliminate inequality of taxpayer treatment, (iii) eliminate lack of transparency and (iv) incentivise taxpayers to pay taxes. In Czech legal literature, it is also pointed out that the problem with unclear legal acts should be solved by amending these acts in ordinary legislative procedure, not by introducing e.g. the institution of tax cancellation based on taxing discretion. ${ }^{6}$

The above opinions may suggest that taxing discretion makes tax decisions arbitrary, i.e. not supported by fair, solid and substantial cause and without reason given. ${ }^{7}$ However, a comparative analysis of English and German law regarding taxing discretion shows something different. In fact, the degree of taxing discretion of the tax authority may vary from solving a problem in an unrestricted manner to solving it under strict guidelines and control of third bodies. There are intermediate solutions as presented below in this comparative analysis, proving that taxing discretion is far from arbitrary.

The author uses the term "taxing discretion" not only because this paper is about tax issues but also to differentiate it from the term "administrative discretion." According to Dominic De Cogan, taxing discretion may be divided into liability discretion, which affects the amounts of tax payable, and administrative discretion, which is connected with tax forms and proceedings strategy, e.g. in an investigation. ${ }^{8}$ In this paper, the author focuses only on liability discretion due to the limited scope of the publication.

The analysis is based on Czech, English and German legal literature and judicature. It is complemented by internal administrative regulations and government statements. The presented parliamentary statutes are predominantly the subject of analysis and interpretation rather than an independent source of knowledge. The analysis presented here is based on the as of 1 March 2020. Such a time restriction is justified by the beginning of the COVID-19

3 Spirit, M., Úvod do studia práva [Introduction to legal study]. Praha 2010, p. 35.

4 Daňový řad [Tax Ordinance], Act no. 280/2009 Coll., as amended.

5 Důvodova zpráva k zákonu č. 267/2014 Sb. [Justification for the Act no. 267/2014 Coll.], Parliament printing no. 252/003.07.2014, Parliament of the Czech Republic: Chamber of Deputies, https://public.psp.cz/en/sqw/text/tiskt. sqw? $\mathrm{ct}=252 \& \mathrm{ct} 1=0 \& \mathrm{o}=7$, accessed 28.06.2018, point 11.28.1.

6 Boňek, V., Ještě jednou k prominutí daně a jejího př́ílušenství [Once more about tax and its incidental dues cancellation], Daňový expert [Tax Expert] 2008, no. 5, 18-19, p. 18.

7 The Law Dictionary, https://thelawdictionary.org/arbitrary/, accessed 28.06.2018.

8 De Cogan, D., Tax, Discretion and the Rule of Law, in Evans, Ch., Freedman, F. (eds.), The Delicate Balance: Tax, Discretion and the Rule of Law. Amsterdam 2011, p. 3. 
pandemic in Europe. The regulations implemented in connection with the pandemic after March 2020 will require a separate analysis after the pandemic.

\section{The Czech Republic}

As indicated above, taxing discretion is criticized in the Czech Republic but, regrettably, it has not yet been the subject of a broader analysis in the Czech tax law literature. On the other hand, discretion has been analysed in administrative law. As Vladimír Mikule acknowledges "administrative authorities are allowed and obliged to act at their own discretion, granting rights and imposing obligations if an act of Parliament grants them the power to resolve the case in different ways (taking the purpose of the regulation into consideration)." Even though such a "reflective" decision is not excluded from judicial review, courts do not control if the administrative authority has chosen the best available option; however, they control if the authority has stayed within the framework of administrative discretion granted by an act of Parliament. Recently, courts have emphasised that an exercise of discretion should not lead to discrimination.

Unfortunately, the above-mentioned statement by Mikule may not concern taxing discretion or may concern it only indirectly. According to $\$ 262$ of the Czech Tax Ordinance, the Czech Code of Administrative Procedure ${ }^{10}$ shall not apply in tax procedure. ${ }^{11}$ Moreover, the exclusion also applies to general principles of administrative law stipulated in $\$ \$ 2-8$ of the Czech Code of Administrative Procedure. According to $\$ 2$ point 2 of the Czech Code of Administrative Procedure, the public authority is obliged to exercise power to achieve the purposes for which the power has been granted. This provision also applies to the power granted with respect to discretion. On the other hand, there are no reasons to interpret discretion in tax law differently than in general administrative law. Such a difference is not presented in commentaries to the Czech Tax Ordinance. Therefore, the above definition by Mikule should be applicable to tax issues but the lack of statutory regulation or comments in the legal literature on this issue is at least meaningful.

The problem of exercising taxing discretion is not a direct subject of tax literature. However, it is briefly mentioned e.g. in comments to the Czech Tax Ordinance. According to one comment, all acts of the tax authority should be rational, comprehensive and foreseeable, which is derived directly from article 2 point 3 of the Constitution of the Czech Republic. ${ }^{12}$ Pursuant to this provision, the power of the state should serve all citizens and may be exercised only within the framework and form of an act of Parliament. It also concerns acts issued with respect to taxing discretion.

In such case, internal administrative guidelines (pokyny) are essential to exercise taxing discretion in the Czech Republic. The guidelines were issued by Minister of Finance till 2011

9 Mikule, V., in Hendrych, D. (ed.), Správní právo. Obecná část [Administrative Law. General Part]. Praha 2011, p. 535.

10 Správní řád [Administrative Procedure Code], no. 500/2004 Coll., as amended.

11 Baxa, J. (ed.), Daňový řad: Komentár [Tax Ordinance. Commentary]. Praha 2011, pp. 1513-1514.

12 Ústava České republiky [Constitution of the Czech Republic], no. 1/1993 Coll., as amended. 
and since then they have been issued by the General Financial Administration (Generální finančni reditelství). ${ }^{13}$ It is worth noting that the guidelines are often very detailed and do not leave the tax authority much freedom in exercising taxing discretion. A good example is pokyn no. GFŘ-D-21 ${ }^{14}$ on cancellation of interests on late tax payment. It is full of tables, including an exhaustive list of factors that the tax authority should consider when cancelling late payment interests and a specification in percentage terms of the allowed cancellations.

The guidelines are not universally binding and the tax authority may even disregard them in its justification of a tax decision. The Supreme Court of the Czech Republic states in the judgement of 25 October 2006 that the tax authority is obligated to apply internal administrative guidelines on exercising taxing discretion unless it is contrary to an act of Parliament. ${ }^{15}$

In practice, the tax authority has not referred directly to the guidelines for several years to avoid being accused of using an extra-parliamentary act to impose taxes. Therefore, the tax authority has citied the content of the guidelines but has not referred to them directly. On the other hand, the tax authority has often rejected taxpayer requests for tax cancellation that were compliant with the guidelines. In such cases, according to the tax authority, the guidelines are not binding.

In the Czech Republic, judicial review over exercising taxing discretion is limited. In the past, the Supreme Administrative Court and the Constitutional Court denied taxpayers the right to control negative decisions on tax cancellation in cases of decisions issued on the basis of taxing discretion. However, the courts changed their position in favour of taxpayers in $2006 .{ }^{16}$ Since then, courts have continued to be cautious in exercising judicial review.

\section{England}

The status of the institution of taxing discretion in England is partly opposite to that in the Czech Republic. The institution is used relatively frequently and is considered indispensable for the tax system. Application of taxing discretion may raise some doubts as England is a country where there were many disputes and even wars over the right to levy taxes between the 14th and 20th centuries. Since the Bill of Rights went into effect in 1688, the power to levy taxes has rested with Parliament. ${ }^{17}$ However, like other administrative bodies in England, the tax authority enjoys significant discretion in exercising its tax competences.

13 Bakeš, M. (ed.), Finanční právo [Financial Law]. Praha 2012, pp. 23-25.

14 Pokyn Generálního finančního ředitelství GFǨ-D-21 k promíjení příslušenství daně [Internal administrative guidelines of the General Financial Administration no. GFř-D-21 on cancellation of late tax payment interests], no. 4260/15/7100-40123, 12.02.2015. Ministry of finance of the Czech Republic, https://www.financnisprava.cz/assets/cs/ prilohy/d-zakony/Pokyn_GFR_D-21.pdf, accessed 28.06.2018.

15 Judgment (rozsudek) of the Supreme Administrative Court of the Czech Republic of 25 October 2006, case no. 8 Afs $3 / 2005 / 59$.

16 Judgment (rozsudek) of the Supreme Administrative Court of the Czech Republic of 24 May 2006, case no. 1 Afs 85/2005-45.

17 Williams, D. et al., Davies: Principles of Tax Law. London 2016, pp. 18-19. 
There are many specific provisions in acts of Parliament that grant the tax authority discretionary power with respect to taxing. ${ }^{18}$ It is also possible to point out some comprehensive clauses granting such discretion. Article 1 point 1 of the Tax Management Act $1970,{ }^{19}$ consolidating the law relating to the administration and collection of taxes, ${ }^{20}$ is the best-known general provisions hereof. According to this provision, "tax shall be under the care and management" of the tax authority. The clause may not look like a taxing discretion clause but the House of Lords acting as a supreme court confirms that the power of care and management authorizes the tax authority to selectively enforce existing tax obligations. ${ }^{21}$

There is also a provision in the Commissioners for Revenue and Customs Act $2005^{22}$ that goes even further regarding taxing discretion. Under article 9 hereof, the tax authority "may do anything which they think: (a) necessary or expedient in connection with exercise of their functions, or (b) incidental or conductive to the exercise of their functions." In the author's opinion, this clause leaves no doubt that taxing discretion is allowed in England and it may be used broadly.

In English legal literature, taxing discretion is divided into the following categories:

1. discretion as to non-application of the law where its interpretation is agreed,

2. discretion as to how to interpret the law,

3. discretion in management of legislation and litigation,

4. hybrids of the above categories. ${ }^{23}$

The above list shows that taxing discretion also has a broad meaning in English law. However, concerning the aforementioned limitation of the subject of this paper to liability discretion, only the first category should be relevant to the article.

According to the traditional view of British administrative law, administrative bodies, including tax administration bodies, are not allowed to transfer their powers to other bodies; however, while realizing the Government's policies they may exercise these powers with full discretion, which is called no-fettering principle. This traditional view is currently being questioned. ${ }^{24}$ Courts have been deviating from the no-fettering principle and have been stating more and more openly that administrative bodies are bound by law of policy. ${ }^{25} \mathrm{On}$ the other hand, the administrative authority can introduce rules on how administrative discretion should be exercised. Guidelines on how taxing discretion should be exercised may also be introduced by other bodies, such as Ombudsman. ${ }^{26}$

18 Freedman, J., HMRC's Management of the U.K. Tax System: The Boundaries of Legitimate Discretion, in Evans, Ch., Freedman, J. (eds.), op. cit., p. 83-84.

19 Tax Management Act 1970, no. 9. legislation.gov.uk.

20 Law, J., Oxford Dictionary of Accounting. New York 2016, p. 426.

21 Judgment of the House of Lords of 9 April 1981, R. v. Inland Revenue Commissioners Ex p. National Federation of Self-Employed and Small Businesses Ltd. 1981, 2 Weekly Law Reports (W.L.R.) 722.

22 Commissioners for Revenue and Customs Act 2005, no. 11. legislation.gov.uk.

23 Freedman, J., op. cit., p. 108.

24 Elliott, M. and Varuhas, J.N.E. (eds.), Administrative Law: Text and Materials. Oxford 2017, p. 160.

25 Ibidem, p. 186.

26 Turpin, C., British Government and the Constitution: Text, Cases and Materials. London 2013, p. 85. 
A tax decision issued through exercising taxing discretion may be the subject of judicial review, which is designed for all public law cases. ${ }^{27}$ The purpose of judicial review is control of executive activities. In the past, Parliament exercised independent control over executive activities but this has changed gradually over the centuries. Nowadays, control is exercised by courts, which in their judgments refer to principles of common law and increasingly to the European Convention of Human Rights. ${ }^{28}$ Although judicial review of the tax authority's activities is an important part of tax law, to this day the constitutional basis for such review is still being disputed. ${ }^{29}$ In addition, Parliament still plays an active role in controlling the activities of the tax authority through its dedicated bodies, such as the Comptroller and Auditor General or the Public Accounts Committee. ${ }^{30}$

To this day, the theoretical basis for judicial review of taxing discretion is the theory of Parliament sovereignty and the ultra vires doctrine. ${ }^{31}$ According to this theory, courts have only a mandate to implement the will of Parliament. ${ }^{32}$ Therefore, courts should focus on verifying whether the activities of the tax authority comply with the powers received from Parliament, i.e. if it has not acted ultra vires. Actions of the tax authority exceeding their powers are void. ${ }^{33}$

The theory of Parliament sovereignty and the ultra vires doctrine have been challenged as the basis for judicial review of taxing discretion. This is particularly evident in cases where courts apply the European Convention of Human Rights and EU law. Therefore, an attempt has been made to alternatively base judicial review on the principle of fairness and other principles of common law. ${ }^{34}$ Such an attempt is referred to as the common law theory of judicial review. It assumes that a court should not only follow the hypothetical will of Parliament, but judicial review should be also based on principles of common law rooted in private law. It should also help to ensure good administration. ${ }^{35}$ In this way, English courts, like German courts, try to determine the limitation of taxing discretion granted to the tax authority. ${ }^{36}$ The scope may be determined by constitutional principles, especially the principle of supremacy of Parliament and the rule of law. ${ }^{37}$

In the English legal literature, we can indicate two views on the described problem majoritarianism and communitarianism. According to majoritarianism, judicial review of taxing discretion should be based solely on the theory of parliamentary sovereignty and the ultra vires doctrine. Under communitarianism, control of taxing discretion should be

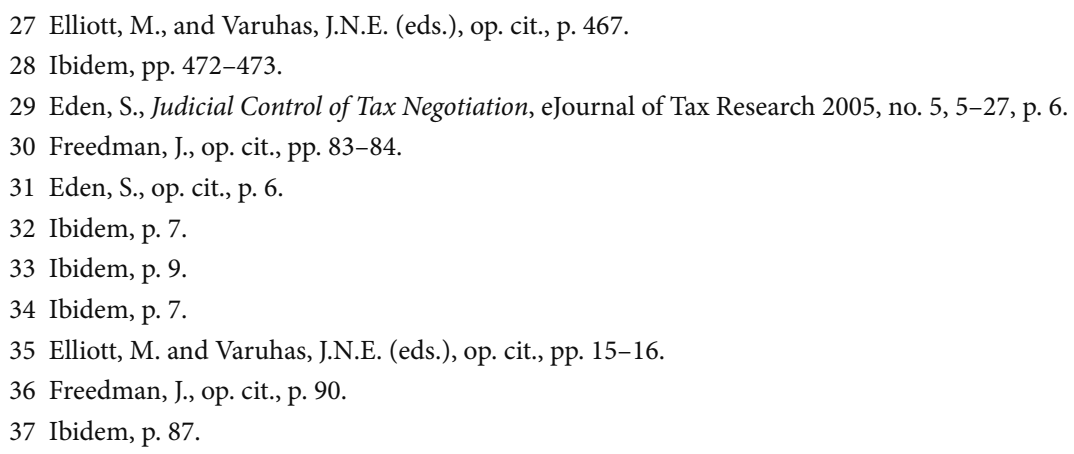


extended to common law. The described division is not clear in judicature; nevertheless, majoritarianism has stronger support among judges. ${ }^{38}$

It should be also emphasized that the introduction of judicial review based on common law is a long process. As pointed out in legal literature, courts deny themselves the right to interfere in substantive aspects of tax decisions and argue that it is matter of policy. ${ }^{39}$ This opinion is especially relevant to, among others, the issue of tax cancellation (UK: extrastatutory concessions). The courts have repeatedly emphasized that according to article 1 of the Tax Management Act 1970 taxes are under care and management of the tax authority. Consequently, courts give priority to the autonomy of the tax authority over the principles of fairness, judicial review and equality. ${ }^{40}$

It is generally accepted that the English tax system would not work without discretion exercised by the tax authority, a view shared by Judith Freedman. However, it is still required to ensure that the limits of discretion are not exceeded. ${ }^{41}$ A situation where the tax authority decides independently if the taxpayer should pay a tax and determines the amount of the tax liabilities represents a radical departure from constitutional principles. ${ }^{42}$ Therefore, taxing discretion as part of tax policy should be regarded as a thing of the past. Nowadays, taxing discretion is increasingly limited by judicial review as well as the doctrine of communitarianism. At the same time, taxing discretion is also partially controlled by internal administrative guidelines and parliamentary committees. The doctrine of communitarianism would also be an inspiration for the Czech legal literature on judicial review of taxing discretion.

\section{Germany}

Unlike English law, German tax law regulations generally do not allow full taxing discretion, ${ }^{43}$ which ostensibly amounts to denial of such discretion. However, certain provisions, such as $₫ 222$ (deferment of payment) or $\$ 227$ (tax cancellation) of the Fiscal Code of Germany, ${ }^{44}$ provide such possibility. Moreover, taxing discretion (Ermessen) as an institution of law is regulated in $\$ 5$ of the Fiscal Code. Pursuant to this paragraph, if the tax authority is authorised to exercise its discretion, it is obliged to do so in compliance with the purpose of the authorisation and to respect statutory restrictions on such discretion. To this end, the tax authority should not confine itself to interpreting the content of statutes but should also consider all written and unwritten law, including international treaties, constitutional law and human rights.

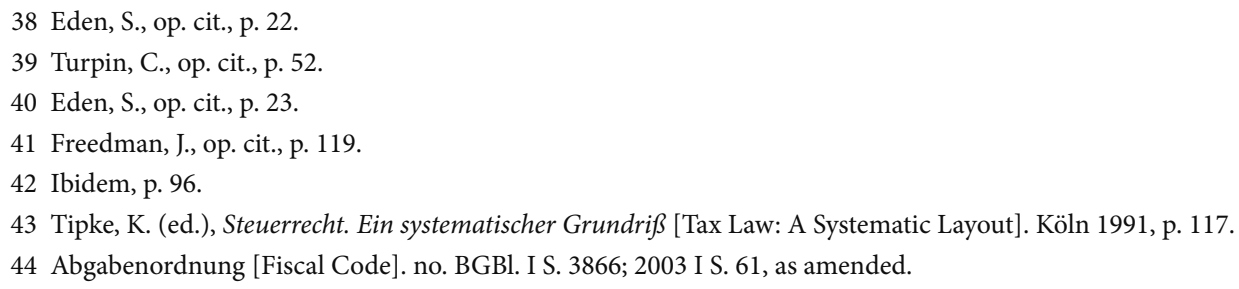


Taxing discretion should always be exercised in conformity with current administrative practices (if such practises exist) and the principles of equality, proportionality, legitimate expectation, good faith and welfare state. ${ }^{45}$ In accordance with the ruling of the Joint Senate of all Federal Supreme Courts tax cancellation in the form of administrative act (Verwaltungsakt) is a discretionary act but its content and scope are limited by inequity. ${ }^{46}$

Additionally, the exercise of taxing discretion is very often regulated by internal administrative guidelines (Verwaltungsanweisungen). The guidelines are not a source of law, but they are binding on the tax authority unless they conflict with legal acts. Therefore, taxpayers have the right to demand that the tax authority exercise taxing discretion in compliance with the guidelines. ${ }^{47}$ Nonetheless, the guidelines are binding only indirectly on the courts $^{48}$ and the legal basis for tax decisions is always a legal act, not an internal administrative guideline. ${ }^{49}$ Moreover, any negative tax act requires justification. In the justification, the tax authority points out why conditions for a positive tax act were not fulfilled and explains why the tax decision is lawful. Additionally, the tax authority should refer to the guidelines if such guidelines apply in the case. ${ }^{50}$

The limitation of judicial review over discretionary tax decisions confirms the freedom of the tax authority to exercise taxing discretion. Theoretically, the taxpayer has no right to challenge a tax decision as part of the exercise of taxing discretion, but there is a visible tendency for a broader judicial review of the exercise of taxing discretion by the tax authority. ${ }^{51}$ Currently, the taxpayer has the right to file a complaint with a court under $\$ 40$ of the German Code of Procedure for Fiscal Courts, ${ }^{52}$ i.e. the right to take action for failure to act. Courts take such a decision on the basis of $\$ 5$ of the Fiscal Code and $\$ 102$ of the Code of Procedure for Fiscal Courts, so courts should only check if taxing discretion was exceeded. According to legal literature, taxing discretion should not be replaced by court discretion. ${ }^{53}$ For that reason, courts may only decide whether a tax act should remain in force or be cancelled. ${ }^{54}$ It is worth noting dynamic changes in understanding of taxing discretion in the German legal system. In the past, it was customarily referred to as free

45 Koenig, U. (ed.), Abgabenordnung: $\$ \$ 1$ bis 368. Kommentar [Fiscal Code: $\$ \$ 1$ to 368. Commentary]. München 2014, pp. $73-75$.

46 Decision (Entscheidung) of the Joint Senate of the Federal Supreme Courts of 19 October 1971, no. Gms-OGB 3/70, Federal Tax Journal II of 1972, p. 603.

47 Klein, F. (ed.), Abgabenordnung - einschließlich Steuerstrafrecht [Fiscal Code - including Criminal Tax Law]. München 2016, pp. 986-987.

48 Judgment (Urteil) of the Federal Fiscal Court of 14 March 2007, no. XI R 59/04, Collection of Judgments of the Federal Fiscal Court 2017, no. 10, p. 1838.

49 Bodden, G., Steuergerechtigkeit im Billigkeitsverfahren nach $\$ 163$ AO [Tax justice in tax cancellation procedure], Deutsches Steuerrecht 2016, no. 30, 1714-1723, p. 1719.

50 Ibidem, p. 1722.

51 Klein, F., op. cit., p. 986.

52 Finanzgerichtsordnung [Code of Procedure for Fiscal Courts], no. BGBl. I S. 442, 2262; 2002 I S. 679, as amended.

53 Koenig, U., op. cit., pp. 76-77.

54 Decision (Entscheidung) of the Federal Fiscal Court of 20 September 2012, no. IV R 29/10, Deutsches Steuerrecht 2012, no. 49, p. 2489. 
discretion (freie Ermessen), but today legal literature indicates that there is only obligatory discretion (pflichtgemäße Ermessen). ${ }^{55}$

Due to the judicial review of tax decisions issued through exercising taxing discretion, we must distinguish two phases of issuing of a tax decision. The first phase determines whether taxing discretion should apply to the facts of the matter (Entschließungsermessen). In the second phase, the tax authority issues a tax decision exercising taxing discretion (Auswahlermessen), which allows issuing decisions with different content. Judicial review covers both phases. A court only checks if taxing discretion was applicable (Ermessenfehlgebrauch) and its exercise was not excessive (Ermessenüberschreitung). ${ }^{56}$ Ostensibly, it allows the tax authority to make extensive use of taxing discretion. However, as indicated above, taxing discretion is limited by current administrative practices and the principles of equality, proportionality, legitimate expectation, good faith and the welfare state. In addition, exercising taxing discretion has to follow the guidelines. Thus, taxing discretion is subject to extensive control by the government and judicial authority.

According to Klaus Tipke and Joachim Lang, taxing discretion in the German tax law system gives the tax authority only a certain amount of flexibility (gewisse Elastizität). If the tax authority were not strictly obliged to exercise taxing discretion within the limits of the authorisation, it would be a breach of the principle of separation of legislative and executive powers. ${ }^{57}$ Therefore, the tax authority is bound by the purposes of an act of Parliament granting taxing discretion and by the guidelines. Additionally, it is controlled by fiscal (administrative) courts.

\section{Conclusion}

Unlimited taxing discretion would undoubtedly be arbitrary, thus confirming allegations expressed in the justification for the draft of the new Czech Tax Ordinance. However, such taxing discretion does not currently exist in the legal systems of England or Germany. Moreover, it is discernible that further limitations on taxing discretion are being imposed, especially in England. On the other hand, German and English law indicates that taxing discretion is an indispensable part of tax law. It is indispensable even in England, where, paradoxically, civil wars were waged to limit the arbitrary power of the Crown in a field of taxation.

Indispensability of taxing discretion does not mean that arbitrary taxing is allowed. According to the above analysis, taxing discretion may be limited by (i) the legal doctrine that exercise of taxing discretion is bound by the purposes of an act of Parliament, including the authorisation for such discretion, constitutional principles or other supreme principles, (ii) judicial review, (iii) internal administrative guidelines, and (iv) control exercised by parliamentary commissions. An appropriate combination of the above limitations should protect

55 Tipke, K. and Kruse, H.W. (eds.), op. cit., p. 4.

56 Klein, F., op. cit., p. 43.

57 Tipke, K. (ed.), op. cit., pp. 117-118. 
against arbitrary actions of the tax authority. It is worth emphasizing that taxing discretion and its limits are still being challenged and modified in all of the above-mentioned countries; in particular, judicial review is undergoing dynamic transformation that should be positively assessed.

Currently, the only instruments used to limit taxing discretion in the Czech Republic are internal administrative guidelines and judicial review. Therefore, it is advisable to introduce further limitations on taxing discretion into Czech legal system, especially to introduce a legal doctrine according to which the exercise of taxing discretion is bound by the purposes of an act of Parliament that granted discretionary power with respect to taxing, constitutional principles or other supreme principles. Such a doctrine already exists in Czech administrative law, but the application of administrative law to tax law is questionable in the Czech Republic. The introduction of this doctrine would reduce the number of negative opinions about taxing discretion in the Czech Republic and would indirectly help to reintroduce tax cancellation into the Czech legal system.

\section{References}

\section{Literature}

Bakeš, M. (ed.), Finanční právo [Financial Law]. Praha 2012.

Baxa, J. (ed.), Daňový řad: Komentár [Tax Ordinance. Commentary]. Praha 2011.

Bodden, G., Steuergerechtigkeit im Billigkeitsverfahren nach \$163 AO [Tax justice in tax cancellation procedure], Deutsches Steuerrecht 2016, no. 30.

Boňek, V., Ještě jednou k prominutí daně a jejího př́ílušenství [Once more about tax and its incidental dues cancellation], Daňový expert [Tax Expert] 2008, no. 5.

De Cogan, D., Tax, Discretion and the Rule of Law, in Evans, Ch., Freedman, F. (eds.), The Delicate Balance: Tax, Discretion and the Rule of Law. Amsterdam 2011.

Eden, S., Judicial Control of Tax Negotiation, eJournal of Tax Research 2005, no. 5.

Elliott, M. and Varuhas, J.N.E. (eds.), Administrative Law: Text and Materials. Oxford 2017.

Freedman, J., HMRC's Management of the U.K. Tax System: The Boundaries of Legitimate Discretion, in Evans, Ch., Freedman, J. (eds.), The Delicate Balance. Tax, Discretion and the Rule of Law. Amsterdam 2011.

Hendrych, D. (ed.), Správní právo. Obecná část [Administrative Law. General Part]. Praha 2011.

Klein, F. (ed.), Abgabenordnung - einschließlich Steuerstrafrecht [Fiscal Code - including Criminal Tax Law]. München 2016.

Koenig, U. (ed.), Abgabenordnung: $\$ \$ 1$ bis 368. Kommentar [Fiscal Code: $\$ \$ 1$ to 368. Commentary]. München 2014.

Law, J., Oxford Dictionary of Accounting. New York 2016.

Spirit, M., Úvod do studia práva [Introduction to legal study]. Praha 2010.

Tipke, K. (ed.), Steuerrecht. Ein systematischer Grundriß [Tax Law: A Systematic Layout]. Köln 1991.

Tipke, K. and Kruse, H.W. (eds.), Abgabenordnung. Finanzgerichtsordnung. Kommentar [Fiscal Code and Code of Procedure for Fiscal Courts: Commentary]. Köln 2014.

Turpin, C., British Government and the Constitution: Text, Cases and Materials. London 2013. 
Williams, D. et al., Davies: Principles of Tax Law. London 2016.

\section{Legislative acts}

Abgabenordnung [Fiscal Code]. no. BGBl. I S. 3866; 2003 I S. 61, as amended.

Commissioners for Revenue and Customs Act 2005, no. 11. legislation.gov.uk.

Daňový řad [Tax Ordinance], Act no. 280/2009 Coll., as amended.

Finanzgerichtsordnung [Code of Procedure for Fiscal Courts], no. BGBl. I S. 442, 2262; 2002 I S. 679, as amended.

Správní řád [Administrative Procedure Code], no. 500/2004 Coll., as amended.

Tax Management Act 1970, no. 9. legislation.gov.uk.

Ústava České republiky [Constitution of the Czech Republic], no. 1/1993 Coll., as amended.

\section{Judicial decisions}

Decision (Entscheidung) of the Federal Fiscal Court of 20 September 2012, no. IV R 29/10, Deutsches Steuerrecht 2012, no. 49.

Decision (Entscheidung) of the Joint Senate of the Federal Supreme Courts of 19 October 1971, no. Gms-OGB 3/70, Federal Tax Journal II of 1972.

Judgment of the House of Lords of 9 April 1981, R. v. Inland Revenue Commissioners Ex p. National Federation of Self-Employed and Small Businesses Ltd. 1981, 2 Weekly Law Reports (W.L.R.) 722.

Judgment (rozsudek) of the Supreme Administrative Court of the Czech Republic of 24 May 2006, case no. 1 Afs 85/2005-45.

Judgment (rozsudek) of the Supreme Administrative Court of the Czech Republic of 25 October 2006, case no. 8 Afs 3/2005/59.

Judgment (Urteil) of the Federal Fiscal Court of 14 March 2007, no. XI R 59/04, Collection of Judgments of the Federal Fiscal Court 2017, no. 10.

\section{Other documents}

Důvodova zpráva k zákonu č. 267/2014 Sb. [Justification for the Act no. 267/2014 Coll.], Parliament printing no. 252/003.07.2014, Parliament of the Czech Republic: Chamber of Deputies, https:// public.psp.cz/en/sqw/text/tiskt.sqw?ct=252\&ctl=0\&o=7, accessed 28.06.2018.

Pokyn Generálního finančního ředitelství GF̌̌-D-21 k promíjení příslušenství daně [Internal administrative guidelines of the General Financial Administration no. GFǨ-D-21 on cancellation of late tax payment interests], no. 4260/15/7100-40123, 12.02.2015. Ministry of finance of the Czech Republic, https://www.financnisprava.cz/assets/cs/prilohy/d-zakony/Pokyn_GFR_D-21. pdf, accessed 28.06.2018.

The Law Dictionary, https://thelawdictionary.org/arbitrary/, accessed 28.06.2018. 